\title{
HUBUNGAN FAKTOR PEMBENTUK PERILAKU \\ DENGAN KEPATUHAN PENGGUNAAN ALAT PELINDUNG TELINGA PADA TENAGA KERJA DI PLTD AMPENAN
}

\author{
Ahmad Candra \\ Ikatan Alumni Kesehatan Masyarakat Indonesia (IAKMI) Provinsi Jawa Timur \\ Email: rachandrachman@gmail.com
}

\begin{abstract}
Safe behaviour in company could prevent Noise Induce Hearing Loss. Safe behaviour that could prevent hearing loss is the compliance of wearing ear protector. It could be shaped by using the activator-behaviour-consequence (ABC) method that can be influenced by forming behaviour factors (knowledge, training, and supervision and positive reinforcement). The aim of this research was to analyze the association between forming behaviour factors with the compliance of wearing ear protector. This was an observational analytic study with cross sectional approach with 18 workers in maintenance section of PLTD Ampenan as sample. Data were collected through questionnaire, interview, and observation. Data were analyzed used pearson chi-square and fisher exact test to obtain the association between variables. The results showed that most of the workers (72.2\%) in maintenance section of PLTD Ampenan had the compliance of wearing ear protector. There were significant correlation between knowledge, training, supervision, and positive reinforcement with the compliance of wearing ear protector. Supervision has a very strong correlation (coefficent 1,000). The more workers feel himself under supervision, the better their behaviour will be. It is recommended that the company can perform all forming behaviour factors especially improve the supervision method in order to make all workers have the compliance of wearing ear protector.
\end{abstract}

Keywords: forming behaviour factor, safe behaviour, $A B C$ method

\begin{abstract}
ABSTRAK
Perilaku aman di perusahaan dapat mencegah masalah gangguan pendengaran akibat kebisingan. Perilaku aman yang dapat mencegahnya adalah kepatuhan penggunaan APT. Pembentukan perilaku kepatuhan penggunaan APT dapat dilakukan menggunakan metode Activator-Behaviour-Consequence (ABC) yang ditentukan oleh faktor pembentuk perilaku (pengetahuan, pelatihan, dan pengawasan, positive reinforcement). Tujuan dari penelitian ini adalah untuk menganalisis hubungan antara faktor pembentuk perilaku dengan kepatuhan penggunaan APT. Studi penelitian ini menggunakan teknik observasional analitik dengan rancangan penelitian cross sectional dengan jumlah sampel 18 tenaga kerja unit pemeliharaan PLTD Ampenan. Data dihimpun melalui kuesioner, wawancara, dan observasi perilaku pekerja. Data dianalisis menggunakan pearson chi-square dan fisher exact test untuk mendapatkan hubungan antar variabel. Hasil penelitian ini menunjukkan 72,2\% pekerja unit pemeliharaan PLTD Ampenan memiliki perilaku patuh menggunakan APT. Hasil uji statistik menunjukkan pengetahuan, pelatihan, pengawasan, dan positive reinforcement memiliki hubungan signifikan dengan perilaku patuh menggunakan APT. Pengawasan memiliki hubungan yang masuk dalam kategori sangat kuat (nilai koefisien 1,000). Semakin tenaga kerja merasa dirinya diawasi, perilaku yang dilakukan semakin baik. Disarankan bagi perusahaan untuk menjalankan semua faktor pembentuk perilaku terutama meningkatkan pengawasan yang bertujuan untuk membentuk perilaku kepatuhan penggunaan APT pada seluruh tenaga kerja.
\end{abstract}

Kata kunci: faktor pembentuk perilaku, perilaku aman, metode $\mathrm{ABC}$

\section{PENDAHULUAN}

Penyakit Akibat Kerja berupa gangguan pendengaran menjadi salah satu masalah di lingkungan kerja. Penyebabnya adalah kebisingan. Kebisingan di lingkungan kerja dapat menimbulkan gangguan pendengaran. Menurut Peraturan Menteri Tenaga Kerja Republik Indonesia No. PER.13/ MEN/X/2011 tentang Nilai Ambang Batas Faktor Fisika dan Faktor Kimia di Tempat Kerja pada
Pasal 1 Ayat 19, kebisingan adalah semua suara yang tidak dikehendaki yang bersumber dari alatalat proses produksi dan atau alat-alat kerja yang pada tingkat tertentu dapat menimbulkan gangguan pendengaran.

Masalah gangguan pendengaran menurut WHO (2010) disebutkan $80 \%$ orang yang mengalami masalah gangguan pendengaran memiliki tempat tinggal di negara berkembang yang memiliki 
kekuatan di bidang industri. Tahun 2001-2005, jumlah masalah gangguan pendengaran meningkat sekitar hampir 30 juta. Di tahun 2005, WHO menambahkan bahwa dari 278 juta orang yang mengalami gangguan pendengaran, 75-140 juta diantaranya berada di Asia Tenggara.

Indonesia merupakan salah satu negara di Asia Tenggara yang merupakan negara berkembang dan memiliki kekuatan di bidang industri. Salah satu yang berkembang adalah industri tenaga listrik. Pada tahun 2006, PT PLN yang merupakan penyedia tenaga listrik di Indonesia mencatat produksi listrik sebesar 133.109,00 GWh. Angka ini meningkat hingga mencapai $160.786,21 \mathrm{GWh}$ pada tahun 2010.

Produksi listrik di Indonesia dihasilkan dari beberapa unit pembangkit listrik. Unit pembangkit listrik yang ada di Indonesia yang terbanyak adalah Pembangkit Listrik Tenaga Diesel (PLTD). Dari 5.541 unit pembangkit yang ada di Indonesia, 4.637 unit merupakan PLTD yang memiliki pangsa sekitar $83,7 \%$. Angka tersebut jauh di atas unit-unit lain yaitu Pembangkit Listrik Tenaga Air (PLTA) 381 Unit, Pembangkit Listrik Tenaga Gas (PLTG) 178 Unit, dan Pembangkit Listrik Tenaga Uap (PLTU) 161 unit.

PLTD memproduksi listrik dengan memanfaatkan mesin diesel. Pemanfaatan mesin diesel memiliki dampak negatif berupa kebisingan yang disebabkan oleh suara mesin. Hal ini menunjukkan bahwa dengan banyaknya unit PLTD di Indonesia risiko terjadinya masalah gangguan pendengaran akibat kebisingan bagi tenaga kerja di PLTD sangat besar.

Pengendalian paparan bising di Indonesia diatur dalam Peraturan Menteri Tenaga Kerja Republik Indonesia No. PER.13/MEN/X/2011 tentang Nilai Ambang Batas Faktor Fisika dan Faktor Kimia di Tempat Kerja pasal 5 Ayat 1 disebutkan bahwa NAB yang ditetapkan untuk kebisingan adalah $85 \mathrm{dBA}$.

Peraturan tersebut dapat diwujudkan oleh PLTD dengan melakukan hirarki pengendalian sumber bahaya. Tarwaka (2008) menyebutkan hirarki pengendalian adalah eliminasi, substitusi, rekayasa teknik, pengendalian administrasi dan alat pelindung $\operatorname{diri}(\mathrm{APD})$.

Hirarki pengendalian sumber bahaya yang paling terakhir yaitu APD. Peraturan Menteri Tenaga Kerja dan Transmigrasi Republik Indonesia No. PER. 08/MEN/VII/2010 tentang Alat Pelindung Diri pasal 1, disebutkan bahwa alat pelindung diri adalah alat yang mempunyai kemampuan untuk melindungi seseorang yang fungsinya mengisolasi sebagian atau seluruh tubuh dari potensi bahaya di tempat kerja. Perusahaan diwajibkan menyediakan APD bagi pekerja di tempat kerja sesuai dengan sumber bahaya yang ada. APD yang sesuai dengan sumber bahaya berupa kebisingan adalah alat pelindung telinga (APT).

APT memiliki jenis yaitu earplug dan earmuff. Alat tersebut dimaksudkan untuk mengendalikan kebisingan yang ada untuk mengurangi risiko timbulnya PAK berupa gangguan pendengaran. PLTD di Indonesia wajib menyediakan APT untuk mencegah hal tersebut terjadi.

Penyediaan APT bagi tenaga kerja di PLTD belum menjamin masalah gangguan pendengaran dapat dicegah. Perusahaan harus melakukan upaya lain untuk membentuk perilaku tenaga kerja. Perilaku yang harus dibentuk adalah kepatuhan penggunaan APT. Pembentukan perilaku tersebut dapat dilakukan dengan menggunakan metode ABC (Activator-Behaviour-Consequence) yang dikemukakan oleh Geller (2001).

Activator memiliki fungsi sebagai pengarah seseorang dalam berperilaku. Behaviour adalah perilaku yang diharapkan untuk dilakukan. Consequence memiliki fungsi penting untuk menentukan apakah perilaku tersebut akan terulang atau tidak.

Pembentukan behaviour berupa kepatuhan penggunaan APT yang menjadi activatornya diantaranya adalah adanya pelatihan yang diberikan untuk tenaga kerja mengenai APT, adanya pengawasan pada saat bekerja, dan pengetahuan tenaga kerja mengenai bahaya kebisingan. Sedangkan yang menjadi consequence-nya adalah positive reinforcement.

Perilaku kepatuhan penggunaan APT merupakan salah satu contoh dari perilaku mengutamakan keselamatan dalam bekerja (safe behaviour). Hal tersebut merupakan salah satu bentuk dari penerapan budaya K3 (safety culture) di perusahaan. Blair (2003) dan Clarke (2000) menyatakan bahwa budaya keselamatan berada dalam budaya organisasi yang meliputi perilaku, sikap, dan persepsi yang menjadi satu kesatuan menghasilkan performansi yang berfungsi sebagai penggerak roda organisasi.

Penerapan budaya K3 di perusahaan merupakan target dari Kementerian Tenaga Kerja dan Transmigrasi untuk menekan angka kecelakaan kerja dan jumlah penyakit akibat kerja yang ada di Indonesia. Selain itu, hal ini juga menjadi upaya dalam menghadapi persaingan global yang ada. (Kemenakertrans, 2014). 
Budaya K3 di perusahaan menurut Cooper (2007) memiliki dampak positif terkait hal menurunkan angka kecelakaan kerja dan PAK. Perusahaan Amtrak di Chicago, berhasil menurunkan angka accident dan PAK sebesar $80 \%$ dalam kurun waktu 12 bulan dan menghemat lebih dari 300.000 USD per tahun. Hal itu merupakan dampak dari penerapan budaya K3 di Perusahaan Amtrak. Kesuksesan tersebut bisa dicontoh oleh perusahaan industri di Indonesia dengan menerapkan budaya K3, sejalan dengan rencana Kementerian Tenaga Kerja dan Transmigrasi mewujudkan Indonesia berbudaya K3 di tahun 2015.

PLTD Ampenan PT PLN (Persero) Sektor Pembangkitan Lombok merupakan suatu perusahaan industri listrik di Indonesia. Risiko timbulnya PAK berupa gangguan pendengaran bagi tenaga kerja di perusahaan ini sangat besar. Hal ini ditunjukkan dengan lingkungan kerja yang memiliki intensitas kebisingan di atas NAB. Titik kebisingan tertinggi berada di area mesin dengan intensitas kebisingan sebesar 92,3 dBA yang berarti melebihi NAB yang ditetapkan. Hal ini berarti, PLTD Ampenan diwajibkan melakukan hirarki pengendalian sumber bahaya salah satunya dengan menyediakan APT. Selain menyediakan APT, perlu pembentukan perilaku kepatuhan penggunaan APT pada tenaga kerja agar pencegahan timbulnya masalah gangguan pendengaran menjadi maksimal. Faktor-faktor yang berpengaruh dalam pembentukan perilaku kepatuhan penggunaan APT dapat dianalisis dengan menggunakan pendekatan metode ABC. Pembentukan perilaku kepatuhan penggunaan APT di perusahaan merupakan salah satu bentuk penerapan dari perusahaan berbudaya K3. Faktor activator perilaku kepatuhan penggunaan APT adalah adanya pelatihan, adanya pengawasan dan pengetahuan. Sedangkan faktor consequence adalah positive reinforcement.

Tujuan penelitian ini adalah menganalisis hubungan faktor-faktor pembentuk perilaku dengan perilaku kepatuhan penggunaan APT pada tenaga kerja di PLTD Ampenan dengan menggunakan metode $\mathrm{ABC}$.

\section{METODE}

Metode penelitian ini adalah penelitian analitik yang menganalisis hubungan variabel tergantung dengan variabel bebas. Rancang bangun yang digunakan pada penelitian ini adalah cross sectional yaitu penelitian yang dilakukan pada satu waktu dan pelaksanaannya bersamaan dengan waktu terjadinya masalah yang sedang diteliti. Ditinjau dari tempat pengambilan data, penelitian ini termasuk penelitian lapangan karena bertujuan untuk memperoleh data primer dan data sekunder pada PLTD Ampenan.

Penelitian ini dilaksanakan pada bulan FebruariJuni 2015 di PLTD Ampenan PT PLN (Persero) Sektor Pembangkitan Lombok. Populasi penelitian ini adalah tenaga kerja di unit pemeliharaan PLTD Ampenan yang berjumlah 22 orang. Besar sampel dalam penelitian ini ditentukan menggunakan rumus perhitungan besar sampel simple random sampling dengan sasaran penelitian bersifat homogen yang memiliki karakter yang sama. Hasilnya 18 orang dari total 22 orang tenaga kerja di unit pemeliharaan PLTD Ampenan menjadi sampel. Cara pengambilan sampel pada penelitian ini dengan menggunakan teknik simple random sampling yaitu dipilih secara acak pada populasi tenaga kerja unit pemeliharaan PLTD Ampenan.

Variabel penelitian ini dibagi menjadi variabel tergantung dan variabel bebas. Variabel tergantung yaitu perilaku kepatuhan penggunaan APT. Sedangkan variabel bebasnya adalah adanya pelatihan mengenai APT, adanya pengawasan saat bekerja, pengetahuan mengenai bahaya kebisingan dan penyakit akibat kerja dan positive reinforcement berupa pujian.

Sebelum pengambilan data, peneliti menjelaskan secara ringkas mengenai penelitian yang akan dilakukan kepada responden. Peneliti juga menjelaskan mengenai perilaku terhadap responden, manfaat langsung untuk responden, hak dan kewajiban yang dimiliki oleh responden, dan efek samping dari penelitian yang akan dilakukan.

Data yang dikumpulkan dalam penelitian ini berupa data primer dan data sekunder. Cara pengambilan data yaitu dengan observasi, kuesioner, wawancara, dan checklist. Data sekunder diperoleh dari studi literatur dan penelitian sejenis yang telah dilakukan serta informasi dari manajemen PLTD Ampenan.

Data yang telah dikumpulkan dianalisis univariat dan bivariat. Analisis univariat mendiskripsikan variabel yang diteliti kemudian disajikan dalam bentuk distribusi frekuensi disertai narasi. Sedangkan analisis bivariat berfungsi untuk menentukan hubungan antara variabel tergantung dengan variabel bebas. Hasil analisis bivariat disajikan dalam bentuk tabulasi silang. Uji analisis bivariat yang digunakan yaitu Pearson Chi-square. Jika ada sel yang mempunyai nilai harapan kurang 
dari 5, maka yang digunakan adalah Fisher's Exact test.

Besar nilai koefisien diinterpretasikan ke dalam beberapa kategori tingkat hubungan menurut Riduwan (2013). Nilai 0,00-0,199 dikategorikan sangat lemah, nilai 0,200-0,399 dikategorikan lemah, nilai 0,400-0,599 dikategorikan cukup kuat, nilai 0,600-0,799 dikategorikan kuat, dan 0,800-1,000 dikategorikan sangat kuat.

\section{HASIL}

Kepatuhan penggunaan APT yang dimaksud adalah wujud level kepatuhan perilaku tenaga kerja dalam mematuhi penggunaan APT pada saat bekerja dan berada di ruang mesin. Penilaian kepatuhan dilakukan dengan melakukan observasi selama 7 hari dengan masing-masing responden diobservasi selama 4 kali dalam waktu yang diacak. Hal ini dilakukan untuk mendapatkan hasil perilaku responden yang sebenarnya dan menghindari bias perilaku responden yang sengaja dilakukan karena mengetahui sedang diamati. Proses observasi dilakukan bersama dengan supervisor. Tenaga kerja dikategorikan patuh apabila dalam 4 kali waktu observasi selalu menggunakan APT. Sedangkan tenaga kerja yang pernah tidak menggunakan APT pada saat observasi, dikategorikan tidak patuh.

Tabel 1. Distribusi Kepatuhan Penggunaan APT Unit Pemeliharaan PLTD Ampenan PT PLN (Persero) Sektor Pembangkitan Lombok tahun 2015

\begin{tabular}{|c|c|c|}
\hline $\begin{array}{c}\text { Kepatuhan Penggunaan } \\
\text { APT }\end{array}$ & Frekuensi & Presentase \\
\hline Patuh & 13 & $72,2 \%$ \\
\hline Tidak Patuh & 5 & $27,8 \%$ \\
\hline Total & 18 & $100,0 \%$ \\
\hline
\end{tabular}

Tabel di atas menunjukkan bahwa selama observasi dilakukan, sebagian besar tenaga kerja selalu menggunakan APT pada saat bekerja yang berarti masuk dalam kategori patuh. Tenaga kerja yang memiliki perilaku tidak patuh menggunakan APT selama observasi dilakukan, paling banyak 2 kali ditemukan tidak menggunakan APT dari total 4 kali waktu observasi. Tidak ada tenaga kerja yang tidak pernah menggunakan APT sama sekali pada saat observasi dilakukan. Namun berdasarkan SOP yang berlaku di perusahaan mengenai pemakaian APD, tenaga kerja diwajibkan selalu menggunakan APT apabila sedang bekerja tidak ada toleransi sedikitpun. Temuan tidak menggunakan APT pada saat observasi dikatakan sebagai perilaku tidak patuh.

Faktor pembentuk yang pertama yaitu adanya pelatihan. Pelatihan yang dimaksudkan yaitu pelatihan mengenai alat pelindung diri yang juga mencakup mengenai APT yang didapatkan oleh tenaga kerja dari perusahaan. Tenaga kerja diberikan kuesioner yang menanyakan pernah atau tidaknya mengikuti pelatihan mengenai APT dan pendapat mengenai ada atau tidaknya pelatihan mengenai APT yang diberikan bagi tenaga kerja oleh perusahaan.

Tabel 2. Distribusi Pelatihan Berdasarkan Persepsi Tenaga Kerja Unit Pemeliharaan PLTD Ampenan PT PLN (Persero) Sektor Pembangkitan Lombok tahun 2015

\begin{tabular}{lcc}
\hline \multicolumn{1}{c}{ Adanya Pelatihan } & Frekuensi & Presentase \\
\hline Ada & 10 & $55,5 \%$ \\
Tidak ada & 8 & $44,5 \%$ \\
\hline Total & $\mathbf{1 8}$ & $\mathbf{1 0 0 , 0} \%$ \\
\hline
\end{tabular}

Tabel di atas, menunjukkan bahwa sebagian besar tenaga kerja $(55,6 \%)$ sudah pernah mendapatkan pelatihan mengenai APT yang diberikan oleh perusahaan. Setiap tenaga kerja yang menyatakan pernah mendapatkan pelatihan memiliki jumlah yang berbeda-beda. Terbanyak tenaga kerja menyatakan sudah mendapatkan pelatihan lebih dari 4 kali mengenai APD. Perusahaan menyatakan memiliki program pelatihan mengenai APD dan berperilaku aman dalam bekerja bagi para tenaga kerja. Namun memang dalam pelaksanaannya belum semua tenaga kerja mendapatkannya.

Faktor yang kedua adalah adanya pengawasan. Pengawasan yang dimaksudkan yaitu pendapat dari tenaga kerja mengenai pengawasan yang dilakukan oleh supervisor mengenai pemakaian APT pada saat bekerja. Tenaga kerja diberikan pilihan untuk menyampaikan persepsinya apakah pada saat bekerja mereka merasa ada pengawasan yang dijalankan oleh pihak perusahaan terkait dengan kepatuhan penggunaan APT atau tidak. Hal ini tidak berdasarkan peraturan yang ada di perusahaan, murni pendapat dari tenaga kerja unit pemeliharaan PLTD Ampenan. 
Tabel 3. Distribusi Pengawasan Berdasarkan Persepsi Tenaga Kerja Unit Pemeliharaan PLTD Ampenan PT PLN (Persero) Sektor Pembangkitan Lombok Tahun 2015

\begin{tabular}{lcc}
\hline Adanya Pengawasan & Frekuensi & Presentase \\
\hline Ada & 13 & $72,2 \%$ \\
Tidak ada & 5 & $27,8 \%$ \\
\hline Total & $\mathbf{1 8}$ & $\mathbf{1 0 0 , 0 \%}$ \\
\hline
\end{tabular}

Pengawasan yang dianggap ada oleh 72,2\% tenaga kerja yaitu adalah adanya supervisor yang melihat langsung kegiatan mereka pada saat bekerja. Tenaga kerja yang menyatakan tidak ada pengawasan merupakan tenaga kerja yang jarang melihat keberadaan supervisor pada saat mereka bekerja.

Faktor yang ketiga adalah pengetahuan. Pengetahuan yang dimaksudkan adalah tingkat pengetahuan responden mengenai bahaya kebisingan dan penyakit akibat kerja. Tenaga kerja diberikan 10 pertanyaan yang berhubungan dengan masalah bahaya kebisingan dan penyakit akibat kerja.

Tabel 4. Distribusi Pengetahuan Tenaga Kerja Unit Pemeliharaan PLTD Ampenan PT PLN (Persero) Sektor Pembangkitan Lombok Tahun 2015

\begin{tabular}{lcc}
\hline \multicolumn{1}{c}{ Pengetahuan } & Frekuensi & Presentase \\
\hline Baik & 10 & $55,5 \%$ \\
Cukup & 3 & $16,7 \%$ \\
Kurang & 5 & $27,8 \%$ \\
\hline Total & $\mathbf{1 8}$ & $\mathbf{1 0 0 , 0 \%}$ \\
\hline
\end{tabular}

Berdasarkan tabel di atas, tenaga kerja memiliki pengetahuan mengenai bahaya kebisingan dan PAK yang baik. 55,5\% tenaga kerja dapat menjawab pertanyaan pada kuesioner yang diberikan dengan total skor di atas 21. Skor di atas 21 menunjukkan pengetahuan mengenai bahaya kebisingan dan PAK masuk dalam kategori baik. Skor antara 13-20 menunjukkan pengetahuan tenaga kerja mengenai bahaya kebisingan dan PAK dalam kategori cukup, sedangkan skor di bawah 13 masuk dalam kategori kurang.

Faktor yang terakhir adalah positive reinforcement. Positive reinforcement yaitu adalah akibat yang muncul apabila responden mematuhi penggunaan APT pada saat bekerja dan di area mesin PLTD Ampenan dalam bentuk mendapatkan penghargaan dari PLTD Ampenan. Penghargaan yang dimaksudkan salah satunya adalah berupa pujian.
Tabel 5. Distribusi Positive Reinforcement Berdasarkan Persepsi Tenaga Kerja Unit Pemeliharaan PLTD Ampenan PT PLN (Persero) Sektor Pembangkitan Lombok Tahun 2015

\begin{tabular}{lcc}
\hline \multicolumn{1}{c}{ Positive Reinforcement } & Frekuensi & Presentase \\
\hline Selalu & 8 & $44,4 \%$ \\
Kadang-kadang & 4 & $22,2 \%$ \\
Tidak pernah & 6 & $33,4 \%$ \\
\hline Total & $\mathbf{1 8}$ & $\mathbf{1 0 0 , 0 \%}$ \\
\hline
\end{tabular}

Berdasarkan tabel di atas, PLTD Ampenan sudah mempunyai program pemberian penghargaan kepada para tenaga kerja yang mematuhi penggunaan APT pada saat bekerja, namun belum semua tenaga kerja mendapatkannya $(33,4 \%)$. Tenaga kerja yang menyatakan selalu mendapatkan penghargaan berupa pujian beberapa diantaranya menyatakan pernah mendapatkan bentuk penghargaan lain berupa award dari pihak perusahaan dengan mendapatkan sejumlah uang dan barang. Award ini diberikan pada peringatan bulan $\mathrm{K} 3$ di perusahaan setiap tahunnya dan termasuk program rutin tahunan yang selalu dilaksanakan oleh perusahaan.

\section{PEMBAHASAN}

Kepatuhan yang diamati adalah perilaku tenaga kerja menggunakan APT pada saat bekerja ataupun berada di ruang mesin. Kepatuhan penggunaan APT merupakan salah satu bentuk dari perilaku safe behaviour yang harus dimiliki oleh tenaga kerja yang memilki lingkungan kerja dengan intensitas kebisingan di atas $85 \mathrm{dBA}$ dengan waktu kerja selama 8 jam per hari atau 40 jam per minggu sesuai dengan peraturan yang tertulis di Peraturan Menteri Tenaga Kerja RI No.PER13/MEN/X/2011 tentang Nilai Ambang Batas Faktor Fisika dan Faktor Kimia di Tempat Kerja. Pemakaian APT merupakan bentuk pengendalian APD yang dilakukan oleh perusahaan untuk mencegah timbulnya ketulian akibat kebisingan yang ada di lingkungan kerja.

Tenaga kerja unit pemeliharaan PLTD Ampenan memiliki waktu kerja kurang lebih 5-6 jam sehari dan area kerjanya terpapar bising sebesar 92,3 dBA. Kecuali untuk waktu tertentu seperti saat overhaul mesin, tenaga kerja unit pemeliharaan memiliki waktu kerja selama hampir 7 jam di area mesin. Lama overhaul biasanya sekitar 40 hari tiap 3 bulan sekali. Dari aturan yang ada di Permenaker No. PER13/MEN/X/2011, untuk besar bising $91 \mathrm{dBA}$ masih dalam ambang batas untuk waktu pajanan 
per harinya 2 jam, sedangkan untuk $94 \mathrm{dBA}$ ambang batas pajanan perharinya yaitu 1 jam. Sedangkan menurut aturan dari Direktorat Bina Kesehatan Kerja Departemen Kesehatan (2006), jika tingkat bising berkisar 90-94 dBA, maka penggunaan APT merupakan hal yang wajib.

Pihak perusahaan telah menyediakan APT untuk para tenaga kerja sebagai bentuk pencegahan timbulnya ketulian akibat paparan bising yang ada sebagai bentuk proteksi personal. Hasil penelitian menunjukkan sebagian besar tenaga kerja unit pemeliharaan telah menunjukkan perilaku patuh dalam menggunakan APT. Sebanyak 13 orang $(72,2 \%)$ selalu menggunakan APT selama 4 kali waktu pengamatan dilakukan. Pengamatan dilakukan dengan bantuan dari supervisor unit pemeliharaan dengan jangka waktu 7 hari dengan masing-masing responden diamati dalam 4 waktu yang berbeda. Hal ini dilakukan untuk mendapatkan perilaku sesungguhnya dari responden pada saat bekerja. Menurut Shapiro (2013) pengamatan dilakukan berulang kali untuk mengurangi bias dan mendapatkan hasil yang nyata.

Tingginya angka tenaga kerja yang telah mematuhi penggunaan APT ini sejalan dengan peraturan yang telah ditetapkan oleh perusahaan yang tercantum dalam SOP APD. Peraturan tersebut mengatur para tenaga kerja untuk menggunakan alat pelindung diri yang telah disediakan dengan benar selama berada di area kerja. APT merupakan salah satu dari beberapa alat pelindung diri yang disediakan oleh perusahaan.

Perusahaan juga menjalankan upaya lain yaitu safety moment. Safety moment adalah kegiatan yang dikhususkan untuk membahas tentang keamanan kerja yang dilakukan disela-sela kegiatan coffee meeting di pagi hari sebelum tenaga kerja memulai pekerjaannya. Pada safety moment, pihak manajemen selalu mengingatkan tenaga kerja untuk memperhatikan keamanan pada saat bekerja. Hal ini bertujuan untuk mencegah kecelakaan kerja dan mengurangi risiko ketulian yang dapat muncul akibat faktor bahaya yang ada di lingkungan kerja. Selain mengingatkan tenaga kerja, pada saat safety moment pihak manajemen juga memberikan waktu untuk para tenaga kerja yang memiliki laporan mengenai kecelakaan kerja atau keluhan yang dialaminya yang berkaitan dengan kesehatan kerja. Tenaga kerja juga berhak memberikan masukan kepada manajemen apabila mereka merasa ada hal yang kurang nyaman berkaitan dengan fasilitas penunjang Keselamatan dan Kesehatan Kerja (K3).
Upaya lain harus dilakukan oleh perusahaan agar memenuhi angka $100 \%$ tenaga kerja mematuhi penggunaan APT pada saat bekerja. Karena perilaku tidak mematuhi penggunaan APT masih dimiliki oleh beberapa tenaga kerja $(27,8 \%)$ unit pemeliharaan. Itu berarti risiko penyakit akibat kerja masih sangat besar terjadi. Tenaga kerja yang melakukan unsafe action (tidak menggunakan APT ketika bekerja) dan didukung oleh adanya bahaya fisik dan mekanik dapat berdampak buruk sehingga salah satunya ketulian yang merupakan penyakit akibat kerja. Terjadinya ketulian pada tenaga kerja di perusahaan merupakan kerugian besar.

Cara perusahaan untuk mengetahui upaya yang dapat dilakukan untuk membentuk perilaku kepatuhan penggunaan APT yaitu dengan melakukan pendekatan pembentukan perilaku metode $\mathrm{ABC}$. Hasil analisis faktor-faktor yang berhubungan dengan perilaku kepatuhan penggunaan APT dapat dijadikan acuan oleh perusahaan untuk melakukan upaya-upaya yang dapat membentuk perilaku kepatuhan penggunaan APT guna mencegah timbulnya gangguan pendengaran.

Perusahaan telah menyediakan APT untuk para tenaga kerja unit pemeliharaan. Jenis APT yang dipilih yaitu earplug yang bersifat nondisposable atau dapat digunakan berkali-kali dengan NRR (Noise Reduction Rating) sebesar 22 dBA. Berdasarkan NRR tersebut didapatkan nilai sesungguhnya setelah dikurangi 7 sebagai safety factor mempertimbangkan perbedaan frekuensi dan rata-rata nilai pengujian di laboratorium berarti $22-7=15$ dBA. Jika dihitung dengan intensitas bising area kerja 92,3 dBA, intensitas bising yang didengar oleh tenaga kerja setelah menggunakan earplug dengan NRR 22 dBA adalah (92,3-15) 77,3 dBA. Hasil tersebut menunjukkan spesifikasi earplug yang disediakan oleh perusahaan berarti sudah memenuhi batas aman intensitas bising yang diterima oleh tenaga kerja dengan lama paparan 8 jam per hari.

Tabel 6 menunjukkan analisis bivariat yang menunjukkan hubungan antara variabel tergantung dengan variabel bebas. Variabel bebas yang pertama yaitu pelatihan. Pelatihan yang dimaksud adalah pelatihan (training) yang diterima oleh tenaga kerja dari perusahaan mengenai alat pelindung diri yang juga mencakup APT. Hubungan pelatihan dengan kepatuhan penggunaan APT berdasarkan tabel 6 didapatkan hasil menggunakan Fisher's Exact Test dengan nilai sigma 0,007 . Hal ini menunjukkan $0,007<0,05$, berarti Ho ditolak atau ada hubungan secara analisa statistik antara pelatihan dengan 
Tabel 6. Hubungan Faktor Pembentuk Perilaku Activator dan Consequence dengan Kepatuhan Penggunaan APT di Unit Pemeliharaan PLTD Ampenan PT PLN (Persero) Sektor Pembangkitan Lombok Tahun 2015

\begin{tabular}{|c|c|c|c|c|c|c|c|c|c|}
\hline \multirow{3}{*}{$\begin{array}{c}\text { Faktor Pembentuk } \\
\text { Perilaku }\end{array}$} & \multicolumn{4}{|c|}{ Kepatuhan Penggunaan APT } & \multirow{2}{*}{\multicolumn{2}{|c|}{ Total }} & \multirow{3}{*}{ Sig } & \multirow{3}{*}{ Koefisien } & \multirow{3}{*}{ Hubungan } \\
\hline & \multicolumn{2}{|c|}{ Patuh } & \multicolumn{2}{|c|}{ Tidak Patuh } & & & & & \\
\hline & $\mathbf{N}$ & $\%$ & $\mathbf{N}$ & $\%$ & $\mathbf{N}$ & $\%$ & & & \\
\hline \multicolumn{10}{|l|}{ Pengetahuan } \\
\hline Baik & 10 & 55,5 & 0 & 0 & 10 & 55,5 & \multirow[t]{4}{*}{0,001} & \multirow[t]{4}{*}{0,707} & \multirow[t]{4}{*}{ Ada hubungan } \\
\hline Cukup & 3 & 16,7 & 0 & 0 & 3 & 16,7 & & & \\
\hline Kurang & 0 & 0 & 5 & 27,8 & 5 & 27,8 & & & \\
\hline Jumlah & 13 & 72,2 & 5 & 27,8 & 18 & 100 & & & \\
\hline \multicolumn{10}{|l|}{ Pelatihan } \\
\hline Ada & 10 & 55,5 & 0 & 0 & 10 & 55,5 & \multirow[t]{3}{*}{0,007} & \multirow[t]{3}{*}{0,693} & \multirow[t]{3}{*}{ Ada hubungan } \\
\hline Tidak & 3 & 16,7 & 5 & 27,8 & 8 & 44,5 & & & \\
\hline Jumlah & 13 & 72,2 & 5 & 27,8 & 18 & 100 & & & \\
\hline \multicolumn{10}{|l|}{ Pengawasan } \\
\hline Ada & 13 & 72,2 & 0 & 0 & 13 & 72,2 & \multirow[t]{3}{*}{0,007} & \multirow[t]{3}{*}{1,000} & \multirow[t]{3}{*}{ Ada hubungan } \\
\hline Tidak & 0 & 0 & 5 & 27,8 & 5 & 27,8 & & & \\
\hline Jumlah & 13 & 72,2 & 5 & 27,8 & 18 & 100 & & & \\
\hline \multicolumn{10}{|l|}{ Positive Reinforcement } \\
\hline Selalu & 8 & 44,4 & 0 & 0 & 8 & 44,4 & \multirow[t]{4}{*}{0,001} & \multirow[t]{4}{*}{0,659} & \multirow[t]{4}{*}{ Ada Hubungar } \\
\hline Kadang-kadang & 4 & 22,2 & 0 & 0 & 4 & 22,2 & & & \\
\hline Tidak Pernah & 1 & 5,6 & 5 & 27,8 & 6 & 33,4 & & & \\
\hline Jumlah & 13 & 72,2 & 5 & 27,8 & 18 & 100 & & & \\
\hline
\end{tabular}

kepatuhan penggunaan APT. Besar keterkaitan ditunjukkan oleh nilai kontingensi Phi sebesar 0,693. Hal ini menunjukkan hubungan keterkaitan berada di kategori kuat. Hal ini sesuai dengan hasil penelitian sebelumnya pernah dilakukan oleh Candra dan Ruhyandi (2008). Mereka menyatakan terdapat hubungan antara pelatihan dengan perilaku penggunaan APD (dalam hal ini APT merupakan salah satu jenis APD). Hal ini dikarenakan masih terdapat beberapa pekerja yang menyatakan bahwa pelatihan yang dilakukan kurang memadai di mana pekerja tersebut mungkin tidak hadir dan tidak mengikuti dengan baik dan benar ketika dilakukan pelatihan.

Filipo dalam Hasibuan (2007) mengatakan pelatihan adalah merupakan suatu usaha peningkatan pengetahuan dan keahlian seorang tenaga kerja untuk mengerjakan suatu pekerjaan tertentu. Peningkatan pengetahuan ini yang menjadi tujuan dari diadakannya pelatihan, karena sesuai dengan pendapat Notoatmodjo (2007) pengetahuan merupakan dasar dari pembentuk perilaku seseorang. Hasil tabulasi silang penelitian ini menunjukkan hal yang sesuai dengan semua pendapat tersebut, di mana dari 10 responden $(55,5 \%)$ yang mengaku pernah mendapatkan pelatihan, semuanya memiliki perilaku mematuhi penggunaan APT. Hal tersebut menunjukkan bahwa memang pelatihan memiliki hubungan dengan pembentukan perilaku mematuhi penggunaan APT.

Perusahan harus memperhatikan penyelenggaraan pelatihan karena masih ada tenaga kerja yang mengaku belum mendapatkan pelatihan. Perlu dilakukan perencanaan yang tepat agar semua tenaga kerja mendapatkan keserataan dalam hal mendapatkan pelatihan. Samsudin (2006) menyatakan bahwa perusahaan harus memperhatikan 5 hal sebelum melakukan pelatihan. 5 hal tersebut yaitu jenis pelatihan apa yang dibutuhkan, siapa yang harus dilatih, lokasi pelatihan, metode pelatihan yang diselenggarakan, dan cara untuk mengetahui efektivitas pelatihan. Peserta pelatihan diutamakan untuk tenaga kerja yang memiliki performance kerja kurang baik dan pengetahuan yang kurang. Dengan menentukan peserta pelatihan yang tepat, maka perusahaan akan mendapatkan hasil nyata dari pelatihan tersebut dalam pekerjaan tenaga kerja setelah mendapatkan pelatihan. Hasil nyata yang dimaksudkan adalah perubahan perilaku tidak patuh menjadi patuh menggunakan APT.

Variabel yang kedua yaitu pengawasan, yang dimaksudkan pengawasan adalah pendapat dari tenaga kerja mengenai pengawasan yang dilakukan oleh perusahaan mengenai pemakaian APT pada saat 
bekerja. Hubungan pengawasan dengan kepatuhan penggunaan APT berdasarkan tabel 6 didapatkan hasil menggunakan Fisher's Exact Test dengan nilai sigma 0,007. Hal ini menunjukkan 0,007 < 0,05 , berarti Ho ditolak atau ada hubungan antara pengawasan dengan kepatuhan penggunaan APT. Besar keterkaitan sangat kuat ditunjukkan dengan nilai kontingensi Phi sebesar 1,000.

Menurut Handayaningrat (1994) pengawasan dilakukan dengan tujuan agar hasil pelaksanaan pekerjaan diperoleh secara efisien dan efektif sesuai dengan rencana yang telah ditentukan sebelumnya. Dalam hal ini pengawasan dilakukan oleh perusahaan yang bertujuan untuk tenaga kerja mematuhi penggunaan APT. Hasil tabulasi silang penelitian ini menunjukkan 13 orang $(72,2 \%)$ yang menyatakan bahwa ada pengawasan dari perusahaan mengenai pemakaian APT ada saat bekerja, semuanya memiliki perilaku patuh menggunakan APT. Sementara 5 orang $(27,8 \%)$ yang menyatakan bahwa pengawasan tersebut tidak ada, semuanya memiliki perilaku tidak patuh menggunakan APT. Hal tersebut menunjukkan bahwa tenaga kerja yang merasa dirinya diawasi, maka akan menunjukkan perilaku yang baik. Sedangkan tenaga kerja yang merasa dirinya tidak diawasi, cenderung menunjukkan perilaku yang kurang baik.

Pihak perusahaan sendiri mengaku sudah menunjuk satu orang dari unit pemeliharaan yang memiliki jabatan sebagai supervisor atau pengawas. Setiap harinya, supervisor ini memiliki tugas untuk mengawasi kinerja dan perilaku tenaga kerja pada saat bekerja. Kenyataan bahwa masih ada responden yang menyatakan bahwa tidak adanya pengawasan yang dilakukan, dikarenakan oleh sikap pekerja yang kurang memiliki rasa segan terhadap supervisor karena menganggapnya sebagai rekan kerja saja. Hal lain yang menjadi penyebab yaitu area kerja yang begitu luas, sedangkan jumlah supervisor hanya 1 orang. Sehingga dalam menjalankan pengawasannya, supervisor tidak dapat optimal mengawasi seluruh tenaga kerja.

Hal tersebut dapat menjadi acuan bagi perusahaan untuk menciptakan metode pengawasan lain agar bisa menunjukkan hasil sesuai dengan yang diinginkan. Birds dan Gerrmain (1990) mengatakan seluruh anggota yang terlibat di perusahaan harus mampu melakukan pengawasan terhadap jalannya operasi perusahaan khususnya dalam hal penggunaan APD. Yang dimaksudkan adalah semua tenaga kerja berhak menjadi pengawas terkait hal penggunaan APT. Ini menunjukkan bahwa perusahaan dapat melakukan upaya lainnya dengan tidak hanya menugaskan seorang supervisor saja yang bertugas untuk mengawasi.

Analisis selanjutnya hubungan dengan variabel pengetahuan. Pengetahuan yang dimaksudkan yaitu pengetahuan tenaga kerja mengenai manfaat dari APT, bahaya kebisingan, dan juga penyakit akibat kerja. Hasil dari jawaban kuesioner kemudian dinilai dan dibagi menjadi 3 kategori yaitu baik, cukup, dan kurang. Berdasarkan tabel 6 didapatkan hubungan pengetahuan dengan kepatuhan penggunaan APT dengan menggunakan uji kontingensi dengan nilai sigma 0,001 . Hal ini menunjukkan $0,001 \mathrm{u}<0,05$, berarti Ho ditolak, atau ada hubungan antara tingkat pengetahuan dengan kepatuhan penggunaan APT. Besar keterkaitan ditunjukkan oleh nilai kontingensi yaitu 0,707 . Nilai kontingensi tersebut menunjukkan hubungan berada di kategori yang kuat.

Hasil penelitian juga menunjukkan hubungan antara pengetahuan dengan kepatuhan penggunaan APT berada dalam kategori besar hubungan yang kuat. Hasil tersebut sesuai dengan pendapat Notoatmodjo (2007) yang menyatakan semakin tinggi pengetahuan seseorang, maka semakin besar pula kemungkinan seseorang berperilaku sesuai dengan pengetahuan yang didapatkannya. Menurut Green dalam Notoatmodjo (2007) perilaku dibentuk salah satunya oleh pengetahuan. Pengetahuan merupakan faktor yang dapat mempermudah terjadinya perilaku dalam diri seseorang karena termasuk dalam faktor predisposing.

Tabel tabulasi silang tabel 6 menunjukkan bahwa semakin baik pengetahuan tenaga kerja maka semakin baik pula perilaku yang dimiliki. Begitu juga sebaliknya, semakin kurang pengetahuan tenaga kerja maka perilaku yang ditunjukkan juga semakin buruk. Terdapat 5 orang $(27,8 \%)$ responden yang memiliki tingkat pengetahuan kurang dan semuanya menunjukkan perilaku tidak mematuhi penggunaan APT. Hal ini harus menjadi perhatian perusahaan untuk mengubah perilaku tenaga kerja tersebut dengan menambahkan edukasi untuk meningkatkan pengetahuannya.

Perusahaan selama ini belum melakukan upaya terkait dengan penambahan pengetahuan tenaga kerja ataupun evaluasi tingkat pengetahuan mengenai bahaya kebisingan dan manfaat penggunaan APT. Pada kegiatan safety moment yang telah rutin dilakukan, belum ada kegiatan yang dilakukan untuk menambah pengetahuan tenaga kerja. Hal ini dapat dilakukan upaya pemberian edukasi tambahan secara informal 
pada saat safety moment dengan membuka diskusi mengenai isu-isu yang terbaru mengenai penyakit akibat kerja yang ditimbulkan oleh kebisingan. Diskusi tersebut ditujukan agar para tenaga kerja mendapatkan pemahaman baru mengenai penyakit akibat kerja, kebisingan, ataupun pentingnya menggunakan APT. Untuk cara formal, perusahaan dapat menunjuk beberapa tenaga kerja yang masih belum berpengetahuan baik untuk diikutkan dalam pelatihan yang berkaitan dengan APT, kebisingan, maupun penyakit akibat kerja. Hal tersebut memiliki tujuan yang sama yaitu untuk menambahkan pengetahuan bagi para tenaga kerja.

Tingkat pengetahuan sangat penting menurut Notoatmodjo (2007) dalam mendasari adopsi perilaku yang bersifat long lasting (awet). Menurutnya adopsi perilaku yang didasari oleh pengetahuan, kesadaran, dan sikap yang positif maka perilaku tersebut akan berlangsung lama. Hal ini yang harus diperhatikan oleh perusahaan untuk terus memantau tingkat pengetahuan tenaga kerjanya.

Hubungan yang terakhir yaitu variabel positive reinforcement. Positive reinforcement yang dimaksud adalah akibat yang muncul apabila responden mematuhi penggunaan APT pada saat bekerja dalam bentuk mendapatkan penghargaan berupa pujian dari pihak manajemen perusahaan Hubungan positive reinforcement dengan kepatuhan penggunaan APT berdasarkan tabel 6 didapatkan hasil menggunakan uji kontingensi dengan nilai sigma sebesar 0,001. Hal ini menunjukkan nilai $0,001<0,05$, berarti Ho ditolak atau ada hubungan antara positive reinforcement dengan kepatuhan penggunaan APT. Besar keterkaitan hubungan ditunjukkan dengan nilai koefisien kontingensi sebesar 0,659 . Hal ini menunjukkan hubungan keterkaitan berada dalam kategori kuat.

Menurut Flemming dan Lardner (2002), tenaga kerja dapat memunculkan perilaku tertentu karena memang keinginan bukan karena keharusan. Keinginan yang dimaksud adalah keinginan untuk memperoleh sesuatu yang diinginkan yang akan mereka dapatkan jika melakukan suatu perilaku tertentu. Contoh dari keinginan ini adalah pujian, insentif, dan lainnya. Hal itu merupakan positive reinforcement. Jika tenaga kerja mengetahui akan mendapatkan sesuatu yang positif akibat dari perilaku mematuhi penggunaan APT pada saat bekerja, maka tenaga kerja akan memunculkan perilaku tersebut pada saat bekerja. Selain karena keharusan untuk menanti peraturan, tenaga kerja juga ingin mendapatkan apa yang mereka inginkan.
Hasil tabulasi silang pada tabel 6 menunjukkan bahwa $44,4 \%$ responden yang menyatakan selalu mendapatkan penghargaan berupa pujian dan $22,2 \%$ yang menyatakan kadang-kadang, semuanya memiliki perilaku patuh menggunakan APT pada saat bekerja. Hal ini menunjukkan bahwa mendapatkan pujian merupakan salah satu bentuk yang dianggap keuntungan oleh sebagian besar tenaga kerja. Pendapat Geller (2001), yang menyatakan penghargaan merupakan penguatan positif yang diterima tenaga kerja ketika berperilaku seperti apa yang ditentukan, sehingga tenaga kerja cenderung berperilaku sesuai dengan yang ditentukan ketika mengetahui apa yang akan didapatkan setelahnya. Sejalan dengan Notoatmodjo (2010), seseorang akan menunjukkan perubahan perilaku jika dapat memberikan keuntungan bagi individu yang bersangkutan.

Hubungan yang kuat antara positive reinforcement dengan kepatuhan penggunaan APT ini sejalan dengan hasil penelitian yang dilakukan oleh Syaaf (2008) yang menghasilkan kesimpulan bahwa pengaruh penghargaan dalam membentuk perilaku aman cukup kuat. Hal tersebut disebabkan oleh adanya sistem penghargaan maka akan menjadi suatu motivasi tenaga kerja untuk berperilaku aman dan melaksanakan pekerjaan dengan senang.

\section{SIMPULAN}

Sebagian besar tenaga kerja unit pemeliharaan PLTD Ampenan memiliki perilaku kepatuhan menggunakan APT. Jenis APT yang digunakan adalah earmuff. APT disediakan oleh pihak perusahaan yang bertujuan untuk mencegah timbulnya PAK.

PLTD Ampenan memberikan pelatihan mengenai APT kepada tenaga kerjanya dan juga selalu melakukan pengawasan kepada tenaga kerja pada saat bekerja terkait perilaku kepatuhan penggunaan APT. Namun pelatihan belum diterima oleh semua tenaga kerja, sedangkan pengawasan yang dijalankan tidak dirasakan oleh semua tenaga kerja. Selain itu, PLTD Ampenan juga memberikan penghargaan berupa pujian kepada tenaga kerja yang menggunakan APT pada saat bekerja.

Tingkat pengetahuan tenaga kerja unit pemeliharaan PLTD Ampenan mengenai bahaya kebisingan dan PAK sebagian besar masuk dalam kategori baik. Tenaga kerja yang memiliki pengetahuan yang baik menunjukkan perilaku kepatuhan penggunaan APT pada saat bekerja. 
Faktor pembentuk perilaku (adanya pelatihan, adanya pengawasan, pengetahuan, dan positive reinforcement) memiliki hubungan yang signifikan dengan perilaku kepatuhan penggunaan APT. Pengawasan menjadi faktor yang memiliki hubungan paling kuat dilihat berdasarkan nilai koefisiensi yang menunjukkan hubungan dengan kepatuhan penggunaan APT berada dalam kategori sangat kuat. Semakin tenaga kerja merasa diawasi, perilaku yang mereka tunjukkan semakin baik.

Hal ini dapat menjadi acuan untuk perusahaan agar memaksimalkan faktor pembentuk perilaku tersebut. Dengan menjalankan faktor pembentuk perilaku yang sudah terbukti memiliki hubungan dengan perilaku kepatuhan penggunaan APT, perusahaan diharapkan dapat mengubah perilaku tenaga kerja yang belum patuh menggunakan APT menjadi patuh.

\section{DAFTAR PUSTAKA}

Bird Jr., E. Frank and Germain L. George. 1990. Practical Loss Control Leadership. Georgia: Loganvile.

Blair, E. 2003. Culture \& Leadership: Seven Key Points for Improved Safety Performance. Journal Professional Safety (6), 18-22.

Candra, Ahmad. 2015. Hubungan Faktor Activator dan Consequence dengan Perilaku Kepatuhan Penggunaan Alat Pelindung Telinga pada Tenaga Kerja PLTD Ampenan PT PLN (Persero) Sektor Pembangkitan Lombok. Skripsi. Surabaya: Universitas Airlangga.

Candra dan Ruhyandi. 2008. Faktor-faktor yang Berhubungan dengan Perilaku Kepatuhan Penggunaan APD Pada Karyawan Bagian Press Shop PT. ALMASINDO Tahun 2008. Jurnal Kesehatan Kartika Stikes A. Yani. Vol. 38: 29-44.

Clarke, S. 2000. Safety Culture: Underspecified and Overrated?. International Journal of management Reviews, 2(1), 65-90.

Cooper, D. 2007, Improving Safety Culture: A Practical Guide. Hull: Applied Behaviour Sciences.

Departemen Kesehatan RI. 2006. Pedoman Konservasi Pendengaran di Tempat Kerja. Direktorat Bina Kesehatan Kerja Departemen Kesehatan RI, Jakarta.
Departemen Tenaga Kerja dan Transmigrasi RI. 2010. Permenakertrans No. 8 Tahun 2010 tentang Alat Pelindung Diri. Jakarta: Peraturan Menteri Tenaga Kerja.

Departemen Tenaga Kerja dan Transmigrasi RI. 2011. Permenakertrans No. 13 Tahun 2011 tentang Nilai Ambang Batas Faktor Fisika dan Faktor Kimia di Tempat Kerja. Jakarta: Peraturan Menteri Tenaga Kerja.

Fleming M. \& R. Lardner. 2002. Strategies to Promote Safe Behavior As Part of a Health and Safety Management System. Norwich, Health and Safety Executive.

Geller, E. Scott. 2001a. The Psychology of Safety Handbook. USA, CRC Press LLC.

Geller, E. Scott. 2001b. Working Safe: How to Help People Actively Care for Health and Safety. $2^{\text {nd }}$ Edition. USA, CRC Press LLC.

Handayaningrat, Soewarno. 1994. Pengantar Studi Ilmu Administrasi dan Manajemen. Jakarta: CV. Haji Masagung.

Hasibuan, Malayu. 2007. Manajemen Sumber Daya Manusia. Jakarta: PT Bumi Aksara.

Keputusan Menteri Tenaga Kerja Republik Indonesia No. 372/MEN/XI/2010 tentang Petunjuk Pelaksanaan Bulan Keselamatan dan Kesehatan Kerja Nasional Tahun 2010-2014.

Notoatmodjo, Soekidjo. 2007. Promosi Kesehatan dan Ilmu Perilaku. Jakarta: Rineka Cipta.

Notoatmodjo, Soekidjo. 2010. Prinsip Dasar Ilmu Kesehatan Masyarakat. Jakarta: Rineka Cipta.

Riduwan. 2013. Metode \& Teknik Menyusun Tesis. Bandung: ALFABETA.

Samsudin, Sadili. 2006. Manajemen Sumber Daya Manusia, cetakan ke-1 Bandung: Pustaka Setia.

Shapiro, Edward. S. 2013. Conducting Systematic Behavioral Observations in Schools: Using the Behavioral Observation of Students in Schools (BOSS) App for Iphone and Android. Pennsylvania: Lehigh University.

Syaaf, Fathul Masruri, 2008. Analisis Perilaku Berisiko (At-Risk Behavior) pada Pekerja Unit Usaha Las Sektor Informal di Kota X Tahun 2008. Skripsi. Jakarta: Universitas Indonesia.

Tarwaka, 2008. Keselamatan dan Kesehatan Kerja. Surakarta: Harapan Press.

WHO. 2010. Deafness and Hearing Imprairment. Diktat Kedokteran. http://www.who.int/ diakses pada 5 Februari 2015 